\title{
South-South Cooperation
}

The United Nations Office for South-South Cooperation (UNOSSC) defines South-South cooperation in its broadest sense as political, economic, social, cultural, environmental, and/or technical collaboration in the forms of knowledge, skills, expertise, and/or resource sharing between countries in the Global South. It can involve one or more of the so-called "developing countries" and the cooperation can occur on bilateral, regional, intraregional, or interregional basis (Lengyel and Malacalza 2011; UNOSSC 2018).

The word "South" in South-South cooperation refers to an arguably contested term of Global South, which broadly refers to the regions of Africa, Asia, Latin America, and Oceania. The term generally excludes Europe and North America, signifying geopolitical difference and global and historical relations of power (Dados and Connell 2012).

Historically, the forms and modalities of South-South cooperation vary contextually to a high degree. Some milestones of broad South-South cooperation include the Bandung Conference of 1955 and the First Session of the United Nations Conference on Trade and Development in 1964 and the following Buenos Aires Plan of Action in 1978. Furthermore, countries of the Global South have significantly increased their participation and leadership in humanitarian action and peacekeeping missions in the 2oth century (Amar 2013).

The role of non-traditional (new or re-emerging) actors in the wider spectrum of development cooperation has expanded in the last two decades, increasingly diversifying and challenging traditional approaches to development assistance and humanitarianism (De Renzio and Seifert 2014; Pickup 2018). For example, some South-South cooperation providers reject the labels of "donor" and "recipient" countries, and rather focus on mutually beneficial peer relationship with partner countries and emphasize the exchange of technical skills (Zimmermann and Smith 2011). South-South cooperation can be seen as creating a new developmental narrative that contests the traditional conditionality-given narrative, which focuses on advancing the donors' ideological interests. Notable Southern donors such as China and India tend to refuse to enter into donor arrangements so they do not interfere with other states' sovereign affairs (Mawdsley 2012). The general focus of South-South aid is in non-tied autonomous development, where strategic priorities are shaped by the countries at the receiving end (Quadir 2013).

Criticism of South-South cooperation cautions against generalizations and assumptions of ubiquitous and unanimous approaches of solidarity between the Global Southern states, and questions the acritical use of the notion of 
"Global South" itself. The diversity of the countries of the Global South, in addition to their different relative positions in international relations, requires contextual analysis of the cooperation (Pacitto and Fiddian-Qasmiyeh 2013). Humanitarian and development aid provided by the Global South has been fragmented owing to the lack of national aid strategies and clear organizational structures to coordinate, manage, monitor, and evaluate new and existing aid programs and needs (Quadir 2013). Further, some scholars argue that the South-South cooperation paradigm faces similar challenges to its NorthSouth counterpart, as both are characterized by involving countries' heterogenic policies, institutional arrangements, and engagements in international initiatives and forums (De Renzio and Seifert 2014).

\section{Salla Turunen}

\section{References}

Amar, P. ed. (2013) Global South to the Rescue: Emerging Humanitarian Superpowers and Globalizing Rescue Industries. Routledge.

Dados, N., Connell, R. (2012) The Global South. Contexts, 11(1): 12-13.

De Renzio, P., Seifert, J. (2014) South-South Cooperation and the Future of Development Assistance: Mapping Actors and Options. Third World Quarterly, 35(10): 1860-1875.

Lengyel, M., Malacalza, B. (2011) What Do We Talk When We Talk About South-South Cooperation? The Construction of a Concept from Empirical Basis. IPSA-ECPR Joint Conference, São Paulo.

Mawdsley, E. (2012) The Changing Geographies of Foreign Aid and Development Cooperation: Contributions from Gift Theory. Transactions of the Institute of British Geographers, 37(2): 256-272.

Pacitto, J., Fiddian-Qasmiyeh, E. (2013) Writing the "Other" into Humanitarian Discourse: Framing Theory and Practice in South-South Humanitarian Responses to Forced Displacement. Rsc Working Paper Series, 93.

Pickup, M. (2018) Evaluating Brazilian South-South Cooperation in Haiti. Third World Quarterly, 39(10): 1941-1961.

Quadir, F. (2013) Rising Donors and the New Narrative of "South-South" Cooperation: What Prospects for Changing the Landscape of Development Assistance Programmes? Third World Quarterly, 34(2): 321-333.

UNOSSC (United Nations Office for South-South Cooperation) (2018) About SouthSouth and Triangular Cooperation. https://www.unsouthsouth.org/about/about -sstc/. 
Zimmermann, F., Smith, K. (2011) More Actors, More Money, More Ideas for International Development Co-Operation. Journal of International Development, 23: 722-738.

\section{Sovereignty}

Sovereignty is a type of power usually ascribed to an actor who can determine the behavior and actions that are permitted within a given territory. In humanitarian arenas, sovereignty may be temporary and unclear as different actors fight for power over the same territory. Sovereignty may also be layered, with different actors controlling different elements of life. For example, religious authorities may hold sovereignty over questions of marriage, child custody, and inheritance, while the regional land registry holds sovereignty over the distribution of seeds and tools. It is very important for humanitarian actors to understand who holds sovereignty over their area of operations. Whoever holds sovereignty is the actor that humanitarian negotiations will take place with as they determine whether and what kind of humanitarian activities are permitted (Fast, Freeman, O'Neill and Rowley 2013).

Commonsense understanding of sovereignty attributes it to states and their regional and local institutions. However, in many places the state only holds nominal sovereignty, while effective sovereignty is exercised by non-state actors (Denham and Lombardi 1996). For humanitarian actors, it is important to understand this distinction between nominal and effective sovereignty because humanitarian work often requires interactions with both levels. While, for example, visa and official permissions are obtained via the state, they may be useless in the actual area of operations if actors who do not recognize state sovereignty exercise effective sovereignty in that region.

The ability to hold on to sovereignty is not only related to brute force, but also to whether the population believes in the legitimacy of the sovereign. This means it is important to understand that while sovereignty is held or exercised it is also embodied in people, institutions, and, of course, deities. To understand better the distribution of power, and the strength of a sovereign actor in their area of operations, humanitarian actors should gather an understanding of whom sovereignty is invested in by recipients of aid.

The question of whether humanitarian agencies can develop into sovereign actors is contested (Hoffmann 2011). A research paper argues that "many gaps in the protection of refugees can be connected to a de facto transfer of 